\title{
Central and Eastern Europe: Real estate development within the second and holiday home markets
}

Received (in revised form): 20 March 2007

\section{Richard Barnett}

runs his own independent consultancy practice, International Leisure Management, providing development consultancy advice on projects in the hotel, leisure and hospitality field. Most of his work is in concept planning, market analysis and pre-construction development and finance of mixed use resorts in Europe. He has worked in over 40 countries across the world and is able to bring a detailed operator/consultant view to new project opportunities.

\begin{abstract}
The second and holiday home market has grown dramatically in the last ten years, with northern Europeans showing a strong appetite for homes in the sun, as part of an integrated resort community, or within new and exiting city locations. Prices have risen and buyers must look further a field for a bargain, few can expect to pay the same price for a second home as for their primary residence. The booming house market in the UK has provided the necessary equity to help acquire such homes, and as this market grows, so do the choices that buyers have, both in where their second home is located and what sort of property they choose to own.

The buying motives are primarily lifestyle changes, holiday opportunity and investment. Retirement to a second home is also high on the agenda, as are security and stability. Second/holiday home destinations must be able to satisfy consumers on many levels; weather, ambiance, infrastructure, views, sport, history and nature are all essential elements within the buying decision. The market is driven by value rather than price, thus creating opportunities for emerging destinations to compete with the more mature resort locations. The CEE countries are well placed to compete successfully within this market; providing access to new and exciting destinations with great beaches, lakes, mountains and history, matched with a product which is competitive in price yet of comparable quality to that seen in western Europe. The challenge for developers is to buy into an emerging market at the right time, to be in a position to acquire the appropriate land parcel, and to obtain planning consent within a dynamic market environment.
\end{abstract}

Richard Barnett International Leisure Management 21 Prince Consort Drive Chislehurst Kent BR7 5SB, UK Tel: + 44 (o) 2082950706 E-mail: rb@ilm-uk.com Web: www.ilm-uk.com

\section{Keywords:}

second and holiday home ownership, CEE countries developing within the tourist markets, development challenges, emerging markets

Journal of Retail and Leisure Property (2007) 6, 137-142. doi:10.1057/palgrave.rlp.5100052 


\section{THE SECOND AND HOLIDAY HOME MARKET}

Ever since the 1960s, when people took package holidays to Spain, there has been demand for a home in the sun! Charter flight travel made possible the opportunity to visit a destination several times a year at a reasonable price while budget airlines have built on this and have created a much wider potential market for second and holiday home ownership abroad. Originally, these holiday homes were built within urbanisations - ghettos of little boxes sold to the northern Europeans for a fraction of the price paid for property at home. These developments provided little supporting infrastructure and buyers would 'go native', half the fun of the adventure!

The market grew and local planning authorities became more demanding, requiring a mix of accommodation types, primarily to ensure sufficient facilities were provided to the transient tourist market. Developers, faced with high construction costs of hotels and supporting infrastructure within resorts (golf courses, marinas, retail and country club environments) had to raise standards and charge more for the real estate component. And so the mixed use resort, the integrated resort community, was born. These developments have flourished throughout the western world and Spain and Portugal provide testament to their success, both financially - for developer and owner, and in satisfying a need.

Mixed use resorts in mature destinations still provide an attractively priced second home, largely because the housing boom in northern Europe has helped maintain the price differential between the cost of a primary residence and the holiday home. The gap is, however closing; it is quite possible to find plots for sale on mature resorts at prices in excess of $€ 700$ per $\mathrm{m}^{2}$, including utilities to site and outline planning. Finished product can cost up to $€ 6,000$ per $\mathrm{m}^{2}$.

This narrowing price differential between the cost of a primary home and a second or holiday home is the key single factor in creating opportunities for developers in Central and Eastern Europe (CEE).

\section{THE SECOND AND HOLIDAY HOME MARKET IN CEE}

If low cost development and easy air access created this market in western Europe, then CEE countries are well positioned to attract demand looking for better value second homes in quality locations. While easy air access may still not be evident in all CEE locations, low land and construction costs have provided the basis for a dramatic growth in construction of, and interest in, second and holiday home developments.

CEE stretches from Estonia in the north down to Turkey, passing on the way countries like Poland, Czech Republic, Hungary, Serbia, Croatia, Montenegro and Bulgaria. Many of these countries were communist states up to the end of the Cold War in 1989, those linked with Russia the former Eastern Bloc, were economically and politically bankrupt; others, such as the Balkan States within the former Federal Republic of Yugoslavia, spent ten years in civil war. 
The expansion of the European Union in 1995, 2004 and more recently in January 2007 has brought the European boundaries right up to the west coast of the Black Sea and as far south as the Bosphorus. This influence has reached deeply within the political, economic and cultural lives of CEE residents. Their political aspirations are toward more democracy, economies are more open and free and culturally they are ready to adopt more western lifestyles.

Great strides had to be made in countries such as Poland and Bulgaria to achieve full EU membership; the Balkan States have further to go, repairing their crumbling bureaucracies and administrations, as well as physical infrastructure and bridges with the EU following war time atrocities. They are moving forward, however, and accession talks are taking place with several countries for EU membership, with Croatia and Montenegro in the fore.

Thus, the political and economic basis for more complete integration with the west is in place, but this is not enough to create a product that northern Europeans want to buy. The needs and expectations of these source markets are very similar, with sun, sea, sand and sport leading. They are value driven, but not necessarily price conscious, they are buying:

- secure, quality environment

- privacy

- exclusivity

- total service provision.

And they are buying for one or more of three primary reasons and which are usually interlinked:

- lifestyle living

- investment

- holiday.

Successful resorts almost exclusively offer one or more views of:

- mountains

- sea

- golf

- lakes.

Apart from golf, many southern CEE countries have these characteristics in great abundance; the beautiful Croatian countryside, beaches and historic towns, the Montenegrin lakes and dramatic coastline, the Bulgarian beaches and wild beauty of the Black Sea. More northerly CEE countries have seen second and holiday home developments within major cities such as Prague and Warsaw, where history and ancient city streets provide the ambiance and attraction for second/holiday home buyers.

While Poland, the three Baltic States and the Czech Republic have been members of the EU since 2004, their growth within the second and holiday home market has not been so dramatic as that experienced within the Balkan States over the last six years. Here the advantage of good 
Mediterranean weather, along with dramatic coastlines and good beaches, has helped encourage development in, perhaps, less stable environments.

Air access is important, allowing second and holiday home owners easy and relatively cheap access to their chosen destinations. UK budget airlines fly to many CEE destinations, such as Poland, Slovakia, Hungary, Czech Republic and Croatia; negotiations are taking place for them to fly into Montenegro and the Baltic States. German, French and Russian budget airlines are also providing routes to some of these countries.

\section{THE CHALLENGE}

Land in CEE states is invariably cheaper than in western Europe, although there are of course exceptions, such as Dubrovnik in Croatia and Sveti Stefan in Montenegro where land with planning for residential development can cost in excess $€ 700$ per $\mathrm{m}^{2}$. Land that is not classified for tourist or urban development and where utilities may not be available is generally priced between $€ 20$ and $€ 90$ per $\mathrm{m}^{2}$.

These issues are not insurmountable, but the first real problem is obtaining title to sufficient land to create the proposed development. Most land in these countries is in private hands, held for generations by the same family in tiny plots. Land compilation has two major difficulties; getting all owners to agree a sensible price and to sell together, and ensuring that legal land title is held by the vendors. Some countries have overcome the latter by guaranteeing that, should title be questioned after the municipality has registered the developer as the new owner, any compensation is paid by central government out of funds set aside for this purpose.

In some circumstances, owners have formed land ownership associations that have the right to negotiate on behalf of all landowners. This is particularly the case where land has been classified for tourist or residential use.

The legal planning process in many CEE countries is as confused and complex as in most western countries, with the added dimension of local bureaucrats seeking an 'incentive' to help the process along! A useful approach to these difficulties is to joint venture with a municipality who may own land within the development parcel. In this way, the process can be moved forward to the benefit of all parties, and it is possible to encourage the municipality to include its own fees as part of their equity position. This is important as in some areas the cost of a construction permit can be as high as $€ 200$ per $\mathrm{m}^{2}$.

There are no short cuts to planning within the CEE, many countries have adopted the same rigorous requirements as western countries; larger projects must satisfy both local and national criteria, environmental impact studies are needed in many cases, set back restrictions must be adhered to and density ratios respected. Planning law can change quickly - with developers facing constraints on their developments that may not have existed when they bought the land.

Funding must invariably be sought from external sources, outside of the CEE. This is not, however, considered a problem as many CEE states 
are either in the EU or in discussions with Brussels that may lead to accession.

\section{MARKET DEMAND}

Mintel published a survey of the UK second and holiday home market in mid-2006. ${ }^{1}$ This shows that in 2004 there were some 250,000 British owners of overseas property, and by 2006 this had risen to 800,000 . Spain is the most popular destination with 43 per cent of owners, followed by France 26 per cent, Australia at 22 per cent and Italy at 21 per cent. Only 7 per cent of respondents expressed an interest in eastern Europe.

A further 3 per cent of respondents said they intend to buy abroad in the future, while 5 per cent plan to sell up in the UK and retire abroad. This could represent as many as 2.0 million new buyers in the near future.

The report showed the motives for buying are:

$\begin{array}{ll}\text { Sun } & 51 \text { per cent } \\ \text { Investment } & 40 \text { per cent } \\ \text { Retirement } & 38 \text { per cent }\end{array}$

While this does not show a strong interest in eastern Europe, the research was conducted in 2005/6 and some CEE countries were only beginning to emerge on the second and holiday home market radar at this time. Even 7 per cent of this market illustrates the potential for a strong demand for product that is only just beginning to emerge in any volume.

Fully integrated resort communities have yet to reach many of these countries, with most developments comprising some 40-60 apartments, or small communities of 20 or more villas. There are, however, several larger projects in the planning stages. These are likely to take place on the Adriatic coast in Croatia or Montenegro and on the Black Sea coast of Bulgaria, where opportunities exist to compile large parcels of land and the demand for secondary accommodation far exceeds supply.

This shortage of supply has forced prices up in a very few years. Three years ago, the western Black Sea coast of Bulgaria was barely emerging from its past as a communist holiday venue; land prices and construction costs were very low and the first developers were able to create high profits, selling product at prices three and four times lower than in comparable western Europe destinations. In 2006 land prices exceeded $€ 100$ per $\mathrm{m}^{2}$, in front line locations but with no planning and no utilities to site. Where these benefits exist, prices rose as high as $€ 300$ per $\mathrm{m}^{2}$ while finished product was being marketed at prices in excess of $€ 2,000$ per $\mathrm{m}^{2}$. This caused the market to stall and now there is some concern that Black Sea resorts are becoming less competitive.

Consumers have such a wide choice of venue and it is not difficult for them to contrast and compare destinations that attract them. The Black Sea coast has great beauty and drama, but offers a very limited summer season from October to April and can be a very forbidding place in winter, particularly to the north of Varna. Tourism infrastructure is not well provided for and the culinary experience is not as varied as other more 
mature destinations. These negatives require that a price differential exists between product here and other locations that may offer better weather and facilities. If this differential is eroded, further sales, and resales, may prove to be difficult.

These are dynamic markets and they move very quickly, as they evolve we may expect to see greater stability in pricing. As more product comes on stream, price competition will take over and we may expect to see higher standards of construction and infrastructure provision, more integrated resorts that are designed to meet the needs of buyers and a greater degree of professionalism in the sales process and after sales care and management.

\section{THE DEVELOPERS RETURNS}

Risk and reward are inseparable and developers seeking new destinations in emerging markets deserve to see a reward that reflects the risks they are taking. Those that started to buy up land three or four years ago are now in a position to bring this to market with planning in place, at prices ten times that which was paid. The risk was high, perhaps it is less so today and developers entering the market must realise that super profits may no longer be achievable.

There are many opportunities to successfully develop second and holiday home communities throughout the CEE, the market is evolving from its dynamic beginnings into a more stable and controlled growth pattern. This may be expected to continue, providing a less risky environment for both the developer and the consumer.

There are still those destinations where western interest is yet to be awakened - is Albania next on the list of places to be?

\section{Reference}

1. Mintel International Group Ltd (2006). The Market for Homes and Housing Overseas, Mintel International Group Ltd., London. 